\title{
Therapeutic Use of Silver Nanoparticles in the Prevention and Arrest of Dental Caries
}

\author{
Claudia Butrón Téllez Girón, ${ }^{1}$ Juan F. Hernández Sierra, ${ }^{2}$ Idania DeAlba-Montero, ${ }^{3}$ \\ María de los A. Urbano Peña, ${ }^{3}$ and Facundo Ruiz $\mathbb{D}^{3}$ \\ ${ }^{1}$ Facultad de Estomatología, Universidad Autónoma de San Luis Potosí, C.P. 78000 San Luis Potosí, Mexico \\ ${ }^{2}$ Facultad de Medicina, Universidad Autónoma de San Luis Potosí, C.P. 78000 San Luis Potosí, Mexico \\ ${ }^{3}$ Facultad de Ciencias, Universidad Autónoma de San Luis Potosí, C.P. 78000 San Luis Potosí, Mexico \\ Correspondence should be addressed to Facundo Ruiz; ruizfacundo1@gmail.com
}

Received 27 March 2020; Revised 20 July 2020; Accepted 31 July 2020; Published 12 August 2020

Academic Editor: Guillermo Mendoza-Diaz

Copyright (C) 2020 Claudia Butrón Téllez Girón et al. This is an open access article distributed under the Creative Commons Attribution License, which permits unrestricted use, distribution, and reproduction in any medium, provided the original work is properly cited.

\begin{abstract}
Dental caries is one of the major diseases of the oral cavity affecting humans worldwide. Different alternatives have been used for its control, but its incidence and prevalence are still high. On the other hand, silver has been used for centuries due to its antimicrobial properties. With advances in nanotechnology, the use and research in nanomaterials has increased, recently, and silver nanoparticles have become an essential part of the dental practice, giving materials physical and chemical improvements in their properties, used for their antibacterial capacity preventing and arresting dental caries. The objective of this review was to examine the use of silver nanoparticles, in the treatment of dental caries in the remineralization of teeth hard tissues, as well as the antimicrobial potential, cytotoxicity, and long-term effectiveness.
\end{abstract}

\section{Introduction}

Dental caries is a disease caused by a specific biofilm that forms acid [1], which begins with demineralization on the enamel surface showing what is called white spot lesion, this stage is represented by white and opaque colour $[2,3]$, and the main pathogens responsible for dental caries Streptococcus mutans and Lactobacillus [3-7]. Although, in recent decades, there has been an advance in dental care, dental caries is a global health problem $[2,8]$ and costly, compromising the health and quality of life of children and adults [1]. The most successful treatments used for the prevention and control of early-stage dental caries are based on the use of fluorides [9-12]. In dentistry, silver has been used for over a century as an antimicrobial agent due to its broad spectrum, low toxicity, and absence of cross-spectrum bacterial resistance [13-18]. Silver nitrate was used for reducing the incidence of caries in the deciduous dentition, as a caries preventive agent for permanent molars, a cavity sterilizing agent, and as a dentine desensitizer $[9,19]$.
Subsequently, in the 1960 s, it was suggested to combine silver with fluoride (silver diamine fluoride) as an anticaries agent for a possible combined effect $[20,21]$. However, its clinical application has been limited due to the black pigmentation produced by its application [9, 22-26].

The use of nanotechnology in dentistry has attracted significant attention in the recent years [1], showing novel methods in the prevention and treatment of caries, controlling plaque-related biofilms, and remineralization of primary dental caries [27], among these methods are the formulations of silver nanoparticles (AgNPs) with antimicrobial properties against a wide variety of microorganisms [1, 9, 28-34].

Silver nanoparticles are considered potent antimicrobial agents and have been proven to be effective in vitro against cariogenic bacteria such as Streptococcus mutans [35], having an antibacterial activity 25 times greater than chlorhexidine, as well as an antiviral and antifungal activity $[33,36]$, so multiple studies have proposed their use in various preparations, showing good results in the treatment of early dental caries $[4,37,38]$. 
For these reasons, the objective of this report is to present a review of the literature on the possible therapeutic use of silver nanoparticles in dentistry, in the remineralization of teeth hard tissues, their mode of action, and biocompatibility.

\section{AgNPs Formulations in Caries Prevention and Arrest}

Dental caries is one of the most widespread diseases in the world, affecting $95 \%$ of the population $[39,40]$ at different stages of their lives $[41,42]$. Several studies have designed formulations containing silver nanoparticles against cariogenic pathogens mainly against Streptococcus mutans, evaluating their minimum inhibitory concentration (MIC) and minimum bactericidal concentration (MBC) and in the control of biofilm formation; showing that they are good oral antimicrobial agents [28-30,43], especially at dimensions between $80100 \mathrm{~nm}$, since cytotoxicity increased to dimensions lower than $20 \mathrm{~nm}$ [44] has been demonstrated (Table 1).

New formulations have been evaluated against cariogenic pathogens and their cytotoxic activity through haemolytic activity in different concentrations provisionally called silver nanofluoride (NSF). MIC and MBC were, respectively, around $33.54 \mu \mathrm{g} / \mathrm{ml}$ and $50.32 \mu \mathrm{g} / \mathrm{ml}$. Silver diamine fluoride (SDF) showed similar values. NFS proved to be an antimicrobial agent similar to silver diamine fluoride, but less cytotoxic; however, the effect was not tested or if it stained the enamel surface [37].

Another important aspect to evaluate is the microhardness of the enamel after remineralization with formulations containing AgNPs and evaluating the cariostatic effects using microhardness and microbiological tests as outcome variables, using Saforide ${ }^{\circledR}$, Cariestop ${ }^{\circledR}$, Ancarie $^{\circledR}$, and Ag-Nano (experimental cariostatic agent). Naturally exfoliated deciduous teeth were submitted to an initial test (after a pH cycle to obtain an initial like-caries lesion) and a final microhardness test (after application of the cariostatic agents), with an antimicrobial effect evaluated with Streptococcus mutans, Escherichia coli, and Enterococcus faecalis strains. All the cariostatic showed an improvement in the remineralization of the enamel, in which Saforide ${ }^{\circledR}$ had a higher percentage of microhardness $28.55 \pm 11.75$ than that of Ag-Nano $14.63 \pm 13.38$. Also, in the agar diffusion tests, a greater inhibition of S. mutans, Enterococcus faecalis, and Escherichia coli by Saforide ${ }^{\circledR}$ was observed than by Ancarie ${ }^{\circledR}$ and Ag-Nano. However, the MIC Ag-Nano inhibited the growth of microorganisms at a concentration lower than the other agents, remineralizing also the enamel of deciduous teeth with initial like-caries lesion [45].

In another study were prepared dentin discs from previously demineralized premolars. SDF (38\%), nano-silver fluoride (NSF) $(3.16 \%, 3.66 \%$, and $4.16 \%)$, and propolis fluoride (PPF) $(3 \%, 6 \%$, and 10\%) were applied and subjected to $\mathrm{pH}$ cycles using a demineralization solution $(\mathrm{pH}$ 4.4) for 30 minutes and a remineralization solution $(\mathrm{pH} \mathrm{7})$ for 10 minutes, and this cycle was performed 6 times a day for 8 days. The amount of calcium, phosphate and fluoride ions on the dentine discs surface was compared by energy dispersive X-ray spectroscopy. The results showed that the levels of calcium ions, phosphate, and fluoride in the NSF and PPF groups increased significantly compared to SDF [48]. According to the previous results and with the same procedures, fluorapatite crystals were found on the dentine surface in the SDF and NSF, as well as greater hardness and increased intensity and quality of apatite crystal compounds [49]; on the other hand, the use of optical coherence tomography images showed a greater remineralization effect of NSF compared to sodium fluoride $(\mathrm{NaF})$ in deciduous teeth [50].

\section{Clinical Evidence}

Although most studies on cariogenic bacteria are still in vitro, in recent years, controlled clinical trials have been conducted to measure the efficacy of silver nanoparticles as anticariogenic agents in remineralization.

A controlled clinical trial was performed on decayed teeth in vivo. A formulation of nanoparticle silver, fluoride, and chitosan (NSF) was used as the experimental group and water as the control group. The caries was diagnosed clinically, and only one application was made, with an evaluation of seven days, five and twelve months. On the seventh day, $81 \%$ of the teeth in the treatment group had arrested cavities and $0 \%$ in the control group. After five months, the treatment group had $72.7 \%$ with arrested caries, and the control group had $27.4 \%$. At 12 months, $66.7 \%$ of the caries lesions treated with NSF were still arrested, while the control group had $34.7 \%$. No dark stains were observed on the teeth [4].

In a similar study, the effect of AgNPs added to a commercial fluoride varnish on remineralization of deciduous teeth was evaluated. The study was conducted in children with white spot lesions in anterior deciduous teeth diagnosed with the DIAGNOdent ${ }^{\circledR}$ laser cavity detection pen to measure tooth demineralization. A mixture of silver nanoparticles (powder) and fluoride varnish (Fluor Protector $\operatorname{Varnish}^{\circledR}$, Vivadent, Schaan, Liechtenstein) was prepared at $0.1 \% \mathrm{wt}$. The teeth were assigned, one tooth of each hemi arc to the experimental treatment which was fluoride varnish adding 0.1\% AgNPs and the other for the control treatment, which was commercial fluoride varnish (Fluor Protector Varnish ${ }^{\circledR}$ ). Each tooth was submitted to these treatments once a week for 3 weeks, and measurements were taken again with the DIAGNOdent ${ }^{\circledR}$ at three months to evaluate changes in remineralization, being higher in treatment with AgNPs with a $p=0.001$ [46].

In another research, the efficacy of silver nanoparticles added to a pit and fissure sealant was evaluated in permanent molars to determine the demineralization of this mixture against a control group. They observed that the conventional sealant presented an average microleakage of $30.6 \%$, and the sealant added with silver nanoparticles showed $33.6 \%$ $(P=\mathrm{NS})$. A three times greater reduction in fluorescence was found in the AgNPs group compared to the conventional group $(p<0.05)$. No associations were found based on sex or age, concluding that the sealant with silver nanoparticles 
TABLE 1: Use of silver nanoparticles in the prevention and arrest of the dental caries.

\begin{tabular}{|c|c|c|c|c|}
\hline Author/year & $\begin{array}{l}\text { Type of study and } \\
\text { intended effect on } \\
\text { caries }\end{array}$ & $\begin{array}{l}\text { Assessment method/combined } \\
\text { strategy }\end{array}$ & $\begin{array}{l}\text { Particle size }(\mathrm{nm}) \text { and } \\
\text { shape/method of } \\
\text { obtaining }\end{array}$ & Outcome \\
\hline $\begin{array}{l}\text { Targino et al. } \\
\text { [37] } 2014\end{array}$ & $\begin{array}{l}\text { Experimental in } \\
\text { vitro caries } \\
\text { prevention }\end{array}$ & $\begin{array}{c}\text { UV-visible, TEM, MIC } 399.33 \mu \mathrm{g} / \mathrm{ml} \\
\text { AgNPs, } 2,334 \mu \mathrm{g} / \mathrm{mL} \text { chitosan, and } \\
10,147 \mu \mathrm{g} / \mathrm{ml} \mathrm{NaF}\end{array}$ & $\begin{array}{l}5.9 \pm 3.8, \text { spherical } \\
\text { chemical synthesis }\end{array}$ & $\begin{array}{l}\text { NSF is a promising anticaries agent, } \\
\text { with low toxicity and the potential } \\
\text { advantage of not to stain teeth black }\end{array}$ \\
\hline $\begin{array}{l}\text { Scarpelli et al. } \\
\text { [45] } 2017\end{array}$ & $\begin{array}{l}\text { Experimental in } \\
\text { vitro caries } \\
\text { prevention }\end{array}$ & $\begin{array}{l}\text { Microhardness testing (knoop-type } \\
\text { penetrator (KHN)) superficial and } \\
\text { internal, ADT MIC } 0.016 \% \mathrm{AgNO}_{3} \text {, } \\
\text { and sodium citrate }\end{array}$ & $\begin{array}{l}\text { NA NA green } \\
\text { synthesis }\end{array}$ & $\begin{array}{l}\text { Ag-nano remineralized deciduous } \\
\text { dental enamel and better bactericidal } \\
\text { activity; it does not cause darkening } \\
\text { in demineralized teeth }\end{array}$ \\
\hline $\begin{array}{l}\text { Santos et al. } \\
\text { [4] } 2014\end{array}$ & $\begin{array}{l}\text { Controlled clinical } \\
\text { trial caries } \\
\text { arresting }\end{array}$ & $\begin{array}{c}\text { ICDAS II } 376.5 \mu \mathrm{g} / \mathrm{ml} \mathrm{AgNPs}, \\
28,585 \mu \mathrm{g} / \mathrm{ml} \text { chitosan, and } \\
5028.3 \mu \mathrm{g} / \mathrm{ml} \mathrm{NaF}\end{array}$ & $\begin{array}{l}3.2 \pm 1.2 \text {, spherical } \\
\text { chemical synthesis }\end{array}$ & $\begin{array}{l}\text { NFS is effective to arrest active } \\
\text { dentine caries in deciduous teeth and } \\
\text { not to stain teeth with one } \\
\text { application per year }\end{array}$ \\
\hline $\begin{array}{l}\text { Butrón-Téllez } \\
\text { Girón et al. } \\
\text { [46] } 2017\end{array}$ & $\begin{array}{l}\text { Controlled clinical } \\
\text { trial caries } \\
\text { prevention }\end{array}$ & $\begin{array}{l}\text { UV-visible, TEM DIAGNOdent }{ }^{\circledR} \\
\text { AgNPs (powder), and Fluor } \\
\text { Protector Varnish }{ }^{\circledR} \text { at } 0.1 \% \mathrm{wt}\end{array}$ & $\begin{array}{l}46 \text { pseudospherical } \\
\text { chemical synthesis }\end{array}$ & $\begin{array}{l}\text { Fluoride varnish with AgNPs was } \\
\text { better in the dental remineralization } \\
\text { than conventional varnish }\end{array}$ \\
\hline $\begin{array}{l}\text { Salas-López } \\
\text { et al. [47] } 2017\end{array}$ & $\begin{array}{l}\text { Controlled clinical } \\
\text { trial caries } \\
\text { prevention }\end{array}$ & $\begin{array}{l}\text { DIAGNOdent }{ }^{\circledR} \text { AgNPs } 98 \mu \mathrm{g} / \mathrm{ml} \text { and } \\
\text { Clinpro }^{\mathrm{TM}} \text { pit, an fissure sealant }\end{array}$ & $\begin{array}{l}\text { 40-80 NA chemical } \\
\text { synthesis }\end{array}$ & $\begin{array}{l}\text { AgNPs added sealant increased } \\
\text { remineralization in permanent first } \\
\text { molars compared to the conventional } \\
\text { sealant }\end{array}$ \\
\hline $\begin{array}{l}\text { Soekanto et al. } \\
\text { [48] } 2017\end{array}$ & $\begin{array}{l}\text { Experimental in } \\
\text { vitro caries } \\
\text { prevention }\end{array}$ & $\begin{array}{c}\text { EDX 3.16, } 3.66 \text { y } 4.16 \% \mathrm{AgNO}_{3}, 5 \mathrm{ml} \\
\text { gelatin, glucose } 13.3 \mathrm{~g} / 40 \mathrm{ml} \text {, distilled } \\
\text { water, and } 4.4 \mathrm{~g} \mathrm{NH}_{4} \mathrm{~F}\end{array}$ & $\begin{array}{l}\text { NA NA green } \\
\text { synthesis }\end{array}$ & $\begin{array}{c}\text { NSF* }^{*} \text { showed an increase in calcium, } \\
\text { phosphate, and fluoride ion levels } \\
\text { compared to SDF }\end{array}$ \\
\hline $\begin{array}{l}\text { Soekanto et al. } \\
\text { [49] } 2017\end{array}$ & $\begin{array}{l}\text { Experimental in } \\
\text { vitro caries } \\
\text { prevention }\end{array}$ & $\begin{array}{c}\text { SEM XRD 3.16, } 3.66 \text { y } 4.16 \% \mathrm{AgNO}_{3} \\
5 \mathrm{ml} \text { gelatin, glucose } 13.3 \mathrm{~g} / 40 \mathrm{ml} \text {, } \\
\text { distilled water, and } 4.4 \mathrm{~g} \mathrm{NH} \mathrm{NH}_{4} \mathrm{~F}\end{array}$ & $\begin{array}{l}\text { NA NA green } \\
\text { synthesis }\end{array}$ & $\begin{array}{l}\text { NSF}^{*} \text { increases the intensity and } \\
\text { quality of apatite crystal components, } \\
\text { increasing remineralization }\end{array}$ \\
\hline $\begin{array}{l}\text { e Silva et al. } \\
\text { [50] } 2019\end{array}$ & $\begin{array}{l}\text { Experimental in } \\
\text { vitro caries } \\
\text { prevention }\end{array}$ & $\begin{array}{l}\text { OCT } .3 \mathrm{~g} / 60 \mathrm{ml} \text { chitosan, } 0.012 \mathrm{~mol} / \mathrm{L} \\
\mathrm{AgNO}_{3} \text {, and } 5500 \mathrm{ppm} \mathrm{NaF}\end{array}$ & $\begin{array}{l}8.7 \pm 3.1 \text { NA chemical } \\
\text { synthesis }\end{array}$ & $\begin{array}{c}\text { NSF has the best effect against caries } \\
\text { compared to conventional fluoride } \\
\text { treatments }\end{array}$ \\
\hline $\begin{array}{l}\text { Tirupathi et al. } \\
\text { [51] } 2019\end{array}$ & $\begin{array}{l}\text { Controlled clinical } \\
\text { trial caries } \\
\text { arresting }\end{array}$ & $\begin{array}{l}\text { UNC-5 probe AgNPs power } \\
0.5 \text { grams containing polyvinyl } \\
\text { pyridoline added to } 10 \mathrm{ml} \text { of } \\
22,6000 \text { ppm of sodium fluoride } \\
\text { varnish (FLUORITOP }{ }_{\text {TM }}^{\mathrm{TM} \text { ) }}\end{array}$ & $-100 \mathrm{NA} N A$ & $\begin{array}{l}\text { Annual application of NSSF is better } \\
\text { than or equal to SDF in preventing } \\
\text { the progression of dentinal caries in } \\
\text { deciduous molars, and it does not } \\
\text { cause dark staining of dentinal tissue }\end{array}$ \\
\hline
\end{tabular}

$\mathrm{AgNO}_{3}$ : silver nitrate, AgNPs: silver nanoparticles, TEM: transmission electron microscopy, OCT: optical coherence tomography, NaF: sodium fluoride, MIC: minimum inhibitory concentration, NSF: silver nitrate, chitosan, and fluoride, $\mathrm{NH}_{4} \mathrm{~F}$ : ammonium fluoride, ICDAS II: International Caries Detection and Assessment System, EDX: energy-dispersive X-ray spectroscopy, NFS* : silver nitrate: gelatin, glucose, and ammonium fluoride, NSSF: nanosilver 5\% and sodium fluoride, ADT: agar diffusion test, EDX: energy-dispersive X-ray spectroscopy, SEM: scanning electron micrograph, XRD: X-ray diffraction.

significantly reduced dental demineralization and probably increased remineralization compared to the conventional sealant [47].

Finally, a study was recently conducted using nanosilver $5 \%$ incorporated sodium fluoride (NSSF) dental varnish and $38 \%$ SDF. No significant differences were observed between the NSSF and SDF groups during their 12-month follow-up. NSSF did not cause dark staining of dentinal tissue [51].

\section{Discussion and Perspectives}

SDF has been used as a gold standard in several investigations [23-25, 52-59] in different concentrations in deciduous teeth with a high risk of active caries $[20,59,60]$, effectively preventing and controlling them $[23,24,57,61-63]$. However, it has shown adverse effects, such as causing ulcerations and staining in oral mucosa [64] that are painful due to accidental contact with the solution $[20,65]$, which may disappear within 48 hours $[21,65]$ and the black staining of carious tissue [65-67] due to the oxidation process of the ionic silver contained in its formulation $[4,68]$; however, as previously demonstrated, the use of a cariostatic agent with silver nanoparticles does not cause darkening in demineralized teeth [46-48, 51]. Besides, practically all studies have demonstrated the anticariogenic and remineralizing effect of silver nanoparticles alone [45] and in combination with various components, being superior to conventional treatments [48-51] such as silver diamine fluoride when applied once a year, with the advantage of not staining black dental tissue, the reason being they do not form oxides when in contact with oxygen in the environment, no metallic taste, and lower cost compared to SDF $[4,51]$.

Although the cariostatic effect on dental tissues has not been clarified yet [4], the effectiveness in arresting cavities can be explained by the synergism of the components of their formulation (nanoparticles of silver, chitosan, and fluoride) [69]. Chitosan is a biocompatible, biodegradable, and nontoxic biopolymer widely known for its activity against a wide range of microorganisms $[69,70]$, including 
Streptococcus mutans [69] and Streptococcus sanguinis [71], and by adding the antibacterial mechanism of silver nanoparticles, the silver ions can adhere to the cell wall and cytoplasmic membrane due to electrostatic attraction and affinity to sulfur proteins leading to disruption of the bacterial envelope. Once the ions enter the cells, the respiratory enzymes are deactivated, generating reactive oxygen species. As phosphorus and sulphur are components of DNA, the interaction of silver ions with these elements can cause problems in DNA replication and cell reproduction. Furthermore, silver ions can inhibit protein synthesis causing structural changes and cell death [72]. Besides, the reduction in the size of silver nanoparticles implies an increase in the contact surface, which is an important condition for the antimicrobial effects of silver and which could prevent black stains on teeth [36], as it occurs after the application of SDF [20] and reduces toxicity [36]. Therefore, the activity and stability of silver nanoparticles are believed to be influenced by the nature of their stabilizing agent (chitosan) within their formulation, having a low level of constant interaction between silver nanoparticles and bacteria $[35,73]$.

Although the use of silver nanoparticles in the medical and dental field is of great importance, knowledge about the effect of human exposure and the possible toxicity of these products is limited [74]. However, haemolytic activity tests were performed to evaluate the cytotoxicity of NSF compared to SDF and found not to cause damage to the human erythrocyte membrane, regardless of the blood type. When evaluating absolute cytotoxicity values, NSF is less toxic than $\operatorname{SDF}(p=0.05)$ [37].

The present review showed that these formulations can prevent and arrest demineralization of deciduous tooth enamel, so it is important to take into account that these have a thickness of their enamel layer thinner than the permanent teeth [75-77], being more prone to the caries progression in comparison with the permanent tooth [76-78]. Despite these disadvantages, the deciduous tooth is more sensitive to fluoride treatments, because its enamel has a higher permeability which is approximately 150 times greater than that of a permanent tooth $[35,75]$. Since this enamel is more sensitive to acid action, the bactericidal potential of silver will be able to increase the effect of fluoride while preserving the remineralization potential [50].

Currently, the use of these formulations with silver nanoparticles and fluoride in different concentrations display a positive effect on dental hard tissue for enamel remineralization in deciduous and permanent teeth, increasing the remineralizing, and they may enhance the performance of fluoride with antimicrobial action of silver added to these formulations, preventing and arresting the carious lesion without causing staining. However, no publication has reported the long-term stability and antibacterial effect of silver nanoparticles and fluoride.

\section{Conclusions}

The investigations conducted in laboratory and clinical trials have shown the superiority of silver nanoparticle compounds in the prevention and arrest of dental caries, without the adverse effect of dental pigmentation. This therapy is easy to use and of a lower cost than SDF.

The benefit of the combination of AgNPs with other components must be examined to know its interaction with dental tissues, as well as to determine ideal concentrations, the optimal size of AgNPs, delivery vehicles, doses related to cellular toxicity, and adverse effects. These studies can guide future clinical application protocol for permanent and deciduous dentition whose structure is different, and the behaviour of the formulations added with silver nanoparticles could show different results.

\section{Data Availability}

The data that support the findings of this study are available on request from the corresponding author.

\section{Conflicts of Interest}

The authors declare that they have no conflicts of interest.

\section{References}

[1] V. T. Noronha, A. J. Paula, G. Durán et al., "Silver nanoparticles in dentistry," Dental Materials, vol. 33, no. 10, pp. 1110-1126, 2017.

[2] L. F. Espinosa-Cristóbal, N. López-Ruiz, D. Cabada-Tarín et al., "Antiadherence and antimicrobial properties of silver nanoparticles against Streptococcus mutans on brackets and wires used for orthodontic treatments," Journal of Nanomaterials, vol. 2018, Article ID 9248527, 11 pages, 2018.

[3] F. Shirani and M. Sakhaiemanesh, "Effect of remineralizing agents on the color change of sound enamel and white spot lesions," JIDS, vol. 9, no. 4, pp. 358-368, 2013.

[4] V. E. Santos Jr, A. Vasconcelos Filho, A. G. Targino et al., "A new "silver-bullet" to treat caries in children-nano silver fluoride: a randomised clinical trial," Journal of Dentistry, vol. 42, no. 8, pp. 945-951, 2014.

[5] V. K. Chugh, K. K. Sahu, and A. Chugh, "Prevalence and risk factors for dental caries among preschool children: a crosssectional study in Eastern India," International Journal of Clinical Pediatric Dentistry, vol. 11, no. 3, pp. 238-243, 2018.

[6] A. Porenczuk, P. Firlej, G. Szczepańska, A. Kolenda, and D. Olczak-Kowalczyk, "The laboratory comparison of shear bond strength and microscopic assessment of failure modes for a glass-ionomer cement and dentin bonding systems combined with silver nanoparticles," Acta of Bioengineering and Biomechanics, vol. 18, no. 2, pp. 59-70, 2016.

[7] T. Eiampongpaiboon, W. O. Chung, J. D. Bryers, K.-H. Chung, and D. C. N. Chan, "Antibacterial activity of gold-titanates on gram-positive cariogenic bacteria," Acta Biomaterialia Odontologica Scandinavica, vol. 1, no. 2-4, pp. 51-58, 2015.

[8] S. S. Gao, S. Zhang, M. L. Mei, E. C.-M. Lo, and C.-H. Chu, "Caries remineralisation and arresting effect in children by professionally applied fluoride treatment-a systematic review," BMC Oral Health, vol. 16, no. 1, p. 12, 2016.

[9] J. J.-Y. Peng, M. G. Botelho, and J. P. Matinlinna, "Silver compounds used in dentistry for caries management: a review," Journal of Dentistry, vol. 40, no. 7, pp. 531-541, 2012.

[10] A. P. Erdem, E. Sepet, G. Kulekci, S. C. Trosola, and Y. Guven, "Effects of two fluoride varnishes and one fluoride/chlorhexidine varnish on Streptococcus mutans and 
Streptococcus sobrinus biofilm formation in vitro," International Journal of Medical Sciences, vol. 9, no. 2, pp. 129-136, 2012.

[11] B. T. Amaechi, P. A. AbdulAzees, D. O. Alshareif et al., "Comparative efficacy of a hydroxyapatite and a fluoride toothpaste for prevention and remineralization of dental caries in children," BDJ Open, vol. 5, no. 1, p. 18, 2019.

[12] W. Qiu, Y. Zhou, Z. Li et al., "Application of antibiotics/ antimicrobial agents on dental caries," BioMed Research International, vol. 2020, Article ID 5658212, 11 pages, 2020.

[13] J. S. Kim, E. Kuk, K. N. Yu et al., "Antimicrobial effects of silver nanoparticles," Nanomedicine: Nanotechnology, Biology and Medicine, vol. 3, no. 1, pp. 95-101, 2007.

[14] A. Panacek, L. Kvítek, R. Prucek et al., "Silver colloid nanoparticles: synthesis, characterization, and their antibacterial activity," The Journal of Physical Chemistry. B, vol. 110, no. 33, pp. 16248-16253, 2006.

[15] N. Stobie, B. Duffy, D. E. McCormack et al., "Prevention of Staphylococcus epidermidis biofilm formation using a lowtemperature processed silver-doped phenyltriethoxysilane sol-gel coating," Biomaterials, vol. 29, no. 8, pp. 963-969, 2008.

[16] D. J. Balazs, K. Triandafillu, P. Wood et al., "Inhibition of bacterial adhesion on PVC endotracheal tubes by RF-oxygen glow discharge, sodium hydroxide and silver nitrate treatments," Biomaterials, vol. 25, no. 11, pp. 2139-2151, 2004.

[17] A. Melaiye and W. J. Youngs, "Silver and its application as an antimicrobial agent," Expert Opinion on Therapeutic Patents, vol. 15, no. 2, pp. 125-130, 2005.

[18] K. S. Fakhruddin, H. Egusa, H. C. Ngo, C. Panduwawala, S. Pesee, and L. P. Samaranayake, "Clinical efficacy and the antimicrobial potential of silver formulations in arresting dental caries: a systematic review," BMC Oral Health, vol. 20, no. 1, p. 160, 2020.

[19] S. Gao, I. Zhao, S. Duffin, D. Duangthip, E. Lo, and C. Chu, "Revitalising silver nitrate for caries management," International Journal of Environmental Research and Public Health, vol. 15 , no. 1 , p. $80,2018$.

[20] A. Rosenblatt, T. C. M. Stamford, and R. Niederman, "Silver diamine fluoride: a caries "Silver-Fluoride bullet"” Journal of Dental Research, vol. 88, no. 2, pp. 116-125, 2009.

[21] Y. O. Crystal and R. Niederman, "Evidence-based dentistry update on silver diamine fluoride," Dental Clinics of North America, vol. 63, no. 1, pp. 45-68, 2019.

[22] B. Y. Liu, L. Mei, C. H. Chu, and E. C. M. Lo, "Effect of silver fluoride in preventing the formation of artificial dentinal caries lesions in vitro," The Chinese Journal of Dental Research: The Official Journal of the Scientific Section of the Chinese Stomatological Association (CSA), vol. 22, no. 4, pp. 273-280, 2019.

[23] C. H. Chu, E. C. M. Lo, and H. C. Lin, "Effectiveness of silver diamine fluoride and sodium fluoride varnish in arresting dentin caries in Chinese pre-school children," Journal of Dental Research, vol. 81, no. 11, pp. 767-770, 2002.

[24] J. C. Llodra, A. Rodriguez, B. Ferrer, V. Menardia, T. Ramos, and M. Morato, "Efficacy of silver diamine fluoride for caries reduction in primary teeth and first permanent molars of schoolchildren: 36-month clinical trial," Journal of Dental Research, vol. 84, no. 8, pp. 721-724, 2005.

[25] R. Yee, C. Holmgren, J. Mulder, D. Lama, D. Walker, and W. van Palenstein Helderman, "Efficacy of silver diamine fluoride for arresting caries treatment," Journal of Dental Research, vol. 88, no. 7, pp. 644-647, 2009.
[26] N. Seifo, H. Cassie, J. R. Radford, and N. P. T. Innes, "Silver diamine fluoride for managing carious lesions: an umbrella review," BMC Oral Health, vol. 19, no. 1, p. 145, 2019.

[27] E. Ahmadian, S. Shahi, J. Yazdani, S. Maleki Dizaj, and S. Sharifi, "Local treatment of the dental caries using nanomaterials," Biomedicine \& Pharmacotherapy, vol. 108, pp. 443-447, 2018.

[28] R. Emmanuel, S. Palanisamy, S.-M. Chen et al., "Antimicrobial efficacy of green synthesized drug blended silver nanoparticles against dental caries and periodontal disease causing microorganisms," Materials Science and Engineering: C, vol. 56, pp. 374-379, 2015.

[29] M. N. Abubacker and C. Sathya, "Synthesis of silver nanoparticles from plant chewing sticks and their antibacterial activity on dental pathogen," Br Biomed Bull, vol. 3, pp. 81-93, 2015.

[30] P. L. L. Freire, T. C. M. Stamford, A. J. R. Albuquerque et al., "Action of silver nanoparticles towards biological systems: cytotoxicity evaluation using hen's egg test and inhibition of Streptococcus mutans biofilm formation," International Journal of Antimicrobial Agents, vol. 45, no. 2, pp. 183-187, 2015.

[31] Z. Lu, K. Rong, J. Li, H. Yang, and R. Chen, "Size-dependent antibacterial activities of silver nanoparticles against oral anaerobic pathogenic bacteria," Journal of Materials Science: Materials in Medicine, vol. 24, no. 6, pp. 1465-1471, 2013.

[32] L. F. Espinosa-Cristóbal, G. A. Martínez-Castañón, E. J. Téllez-Déctor, N. Niño-Martínez, N. V. Zavala-Alonso, and J. P. Loyola-Rodríguez, "Adherence inhibition of Streptococcus mutans on dental enamel surface using silver nanoparticles," Materials Science and Engineering: C, vol. 33, no. 4, pp. 2197-2202, 2013.

[33] A. Besinis, T. De Peralta, and R. D. Handy, “The antibacterial effects of silver, titanium dioxide and silica dioxide nanoparticles compared to the dental disinfectant chlorhexidine onStreptococcus mutansusing a suite of bioassays," Nanotoxicology, vol. 8, no. 1, pp. 1-16, 2014.

[34] A. C. Burduşel, O. Gherasim, A. M. Grumezescu, L. Mogoantă, A. Ficai, and E. Andronescu, "Biomedical applications of silver nanoparticles: an up-to-date overview," Nanomaterials (Basel), vol. 8, no. 9, p. 681, 2018.

[35] J. A. Teixeira, A. V. C. e. Silva, V. E. d. Santos Júnior et al., "Effects of a new nano-silver fluoride-containing dentifrice on demineralization of enamel and streptococcus mutans adhesion and acidogenicity," International Journal of Dentistry, vol. 2018, Article ID 1351925, 9 pages, 2018.

[36] J. F. Hernández-Sierra, F. Ruiz, D. C. Cruz Pena et al., “The antimicrobial sensitivity of Streptococcus mutans to nanoparticles of silver, zinc oxide, and gold," Nanomedicine: Nanotechnology, Biology and Medicine, vol. 4, no. 3, pp. 237-240, 2008.

[37] A. G. R. Targino, M. A. P. Flores, V. E. dos Santos Junior et al., "An innovative approach to treating dental decay in children. A new anti-caries agent," Journal of Materials Science: Materials in Medicine, vol. 25, no. 8, pp. 2041-2047, 2014.

[38] R. Haghgoo, H. Saderi, M. Eskandari, H. Haghshenas, and M. Rezvani, "Evaluation of the antimicrobial effect of conventional and nanosilver-containing varnishes on oral streptococci," Journal of Dentistry, vol. 15, no. 2, pp. 57-62, 2014.

[39] P. L. L. Freire, A. J. R. Albuquerque, F. C. Sampaio et al., "AgNPs: the new allies against S. mutans biofilm-a pilot clinical trial and microbiological assay," Brazilian Dental Journal, vol. 28, no. 4, pp. 417-422, 2017. 
[40] D. J. Smith, "Dental Caries vaccines:prospects and concerns," Critical Reviews in Oral Biology \& Medicine, vol. 13, no. 4, pp. 335-349, 2002.

[41] H. R. Ghorbani, "The study of anticariogenic effect of silver nanoparticles for dental applications," International Journal of Nano Dimension, vol. 8, no. 4, pp. 361-364, 2017.

[42] J. M. Ten Cate, "Novel anticaries and remineralizing agents," Journal of Dental Research, vol. 91, no. 9, pp. 813-815, 2012.

[43] S. A. Soekanto, L. J. Marpaung, H. Ushohwah, A. Djais, and R. R. Darwita, "Efficacy of propolis fluoride and nano silver fluoride for inhibition of Streptococcus mutans and Enterococcus faecalis biofilm formation," International Journal of Applied Pharmaceutics, vol. 9, no. 2, pp. 51-54, 2017.

[44] J. F. Hernández-Sierra, O. Galicia-Cruz, A. Salinas-Acosta et al., "In vitroCytotoxicity of silver nanoparticles on human periodontal fibroblasts," Journal of Clinical Pediatric Dentistry, vol. 36, no. 1, pp. 37-42, 2011.

[45] B. B. Scarpelli, M. F. Punhagui, M. G. Hoeppner et al., "In vitro evaluation of the remineralizing potential and antimicrobial activity of a cariostatic agent with silver nanoparticles," Brazilian Dental Journal, vol. 28, no. 6, pp. 738-743, 2017.

[46] C. Butrón-Téllez Girón, J. Mariel-Cárdenas, M. PierdantPérez, J. F. Hernández- Sierra, J. E. Morales-Sánchez, and F. Ruiz, "Effectiveness of a combined silver nanoparticles/ fluoride varnish in dental remineralization in children: in vivo study," Superf. Vacío.vol. 30, no. 2, pp. 21-24, 2017.

[47] E. Salas-López, M. Pierdant-Pérez, J. F. Hernández-Sierra, F. Ruiz, P. Mandeville, and A. Pozos-Guillén, "Effect of silver nanoparticle-added pit and fissure sealant in the prevention of dental caries in children," Journal of Clinical Pediatric Dentistry, vol. 1, no. 41, pp. 48-52, 2017.

[48] S. A. Soekanto, N. Rosithahakiki, D. F. S. Sastradipura, and M. Sahlan, "Comparison of the potency of several fluoridebased varnishes as an anticariogenic on calcium, phosphate, and fluoride ion levels," International Journal of Applied Pharmaceutics, vol. 9, no. 2, pp. 55-59, 2017.

[49] S. A. Soekanto, F. Fadillah, P. Nuraisiya, F. Gultom, and A. T. Sarwono, "The potential of several fluoride-based varnishes as remineralization agents: morphological studies, dentin surface hardness, and crystallinity tests," International Journal of Applied Pharmaceutics, vol. 9, no. 2, pp. 60-66, 2017.

[50] A. V. C. e Silva, J. de Araújo Teixeira, P. C. de Melo Júnior et al., "Remineralizing potential of nano-silver-fluoride for tooth enamel: an optical coherence tomography analysis," Brazilian Research in Pediatric Dentistry and Integrated Clinic, vol. 19, no. 1, Article ID e4002, 2019.

[51] S. Tirupathi, N. Svsg, S. Rajasekhar, and S. Nuvvula, "Comparative cariostatic efficacy of a novel Nano-silver fluoride varnish with $38 \%$ silver diamine fluoride varnish a doubleblind randomized clinical trial," Journal of Clinical and Experimental Dentistry, vol. 11, no. 2, pp. e105-e112, 2019.

[52] M. M. Braga, F. M. Mendes, M. S. De Benedetto, and J. C. Imparato, "Effect of silver diammine fluoride on incipient caries lesions in erupting permanent first molars: a pilot study," Journal of Dentistry for Children, vol. 76, no. 1, pp. 28-33, 2009.

[53] Q. H. Zhi, E. C. M. Lo, and H. C. Lin, "Randomized clinical trial on effectiveness of silver diamine fluoride and glass ionomer in arresting dentine caries in preschool children," Journal of Dentistry, vol. 40, no. 11, pp. 962-967, 2012.

[54] V. E. dos Santos Jr., F. M. N. de Vasconcelos, A. G. Ribeiro, and A. Rosenblatt, "Paradigm shift in the effective treatment of caries in schoolchildren at risk," International Dental Journal, vol. 62, no. 1, pp. 47-51, 2012.

[55] B. Y. Liu, E. C. M. Lo, C. H. Chu, and H. C. Lin, "Randomized trial on fluorides and sealants for fissure caries prevention," Journal of Dental Research, vol. 91, no. 8, pp. 753-758, 2012.

[56] B. Monse, R. Heinrich-Weltzien, J. Mulder, C. Holmgren, and H. WHvP, "Caries preventive efficacy of silver diammine fluoride (SDF) and ART sealants in a school-based daily fluoride toothbrushing program in the Philippines," $B M C$ Oral Health, vol. 12, 2012.

[57] D. Duangthip, C. H. Chu, and E. C. M. Lo, "A randomized clinical trial on arresting dentine caries in preschool children by topical fluorides-18 month results," Journal of Dentistry, vol. 44, pp. 57-63, 2016.

[58] M. H. T. Fung, D. Duangthip, M. C. M. Wong, E. C. M. Lo, and C. H. Chu, "Arresting dentine caries with different concentration and periodicity of silver diamine fluoride," JDR Clinical \& Translational Research, vol. 1, no. 2, pp. 143-152, 2016.

[59] B. H. Oliveira, A. Rajendra, A. Veitz-Keenan, and R. Niederman, "The effect of silver diamine fluoride in preventing caries in the primary dentition: a systematic review and meta-analysis," Caries Research, vol. 53, no. 1, pp. 24-32, 2019.

[60] C. H. Chu and E. C. Lo, "Promoting caries arrest in children with silver diamine fluoride: a review," Oral Health \&amp; Preventive Dentistry, vol. 6, no. 4, pp. 315-321, 2008.

[61] S. Shah, V. Bhaskar, S. Chawla et al., "Efficacy of silver diamine fluoride as a topical fluoride agent compared to fluoride varnish and acidulated phosphate fluoride gel: an in vivo study," Journal of Pediatric Dentistry, vol. 2, no. 1, pp. 5-12, 2014.

[62] J. A. Horst, "Silver fluoride as a treatment for dental caries," Advances in Dental Research, vol. 29, no. 1, pp. 135-140, 2018.

[63] S. S. Gao, K. J. Chen, D. Duangthip, M. C. M. Wong, E. C. M. Lo, and C. H. Chu, "Preventing early childhood caries with silver diamine fluoride: study protocol for a randomised clinical trial," Trials, vol. 21, no. 1, p. 140, 2020.

[64] J. Gupta, M. S. Thomas, M. Radhakrishna, N. Srikant, and K. Ginjupalli, "Effect of silver diamine fluoride-potassium iodide and $2 \%$ chlorhexidine gluconate cavity cleansers on the bond strength and microleakage of resin-modified glass ionomer cement," Journal of Conservative Dentistry, vol. 22, no. 2, pp. 201-206, 2019.

[65] R. García-Contreras, L. Argueta-Figueroa, C. Mejía-Rubalcava et al., "Perspectives for the use of silver nanoparticles in dental practice," International Dental Journal, vol. 61, no. 6, pp. 297-301, 2011.

[66] A. G. R. Targino, M. A. P. Flores, V. E. Santos Junior, H. L. F. Pessoa, A. Galembeck, and A. Rosenblatt, "Antimicrobial activity of silver nanoparticles in treating dental caries," RFO UPF, vol. 18, pp. 312-315, 2013.

[67] A. F. Alshammari, A. A. Almuqrin, A. M. Aldakhil, B. H. Alshammari, and J. N. J. Lopez, "Parental perceptions and acceptance of silver diamine fluoride treatment in Kingdom of Saudi Arabia," International Journal of Health Sciences, vol. 13, no. 2, pp. 25-29, 2019.

[68] M. H. T. Fung, M. C. M. Wong, E. C. M. Lo, and C. H. Chu, "Arresting early childhood caries with silver diamine fluorideA literature review," Journal of Oral and Dental Health Research, vol. 1, pp. 1-5, 2013.

[69] V. R. Nagireddy, D. Reddy, S. Kondamadugu, N. Puppala, A. Mareddy, and A. Chris, "Nanosilver fluoride-A paradigm shift for arrest in dental caries in primary teeth of 
schoolchildren: a randomized controlled clinical trial," International Journal of Clinical Pediatric Dentistry, vol. 12, no. 6, pp. 484-490, 2019.

[70] E. I. Rabea, M. E.-T. Badawy, C. V. Stevens, G. Smagghe, and W. Steurbaut, "Chitosan as antimicrobial agent: applications and mode of action," Biomacromolecules, vol. 4, no. 6, pp. 1457-1465, 2003.

[71] K. Bae, E. J. Jun, S. M. Lee, D. I. Paik, and J. B. Kim, "Effect of water-soluble reduced chitosan on Streptococcus mutans, plaque regrowth and biofilm vitality," Clinical Oral Investigations, vol. 10, no. 2, pp. 102-107, 2006.

[72] I. X. Yin, J. Zhang, I. S. Zhao, M. L. Mei, Q. Li, and C. H. Chu, "The antibacterial mechanism of silver nanoparticles and its application in dentistry," International Journal of Nanomedicine, vol. 15, pp. 2555-2562, 2020.

[73] S. C. Hamm, R. Shankaran, V. Korampally et al., "Sputterdeposition of silver nanoparticles into ionic liquid as a sacrificial reservoir in antimicrobial organosilicate nanocomposite coatings," ACS Applied Materials \& Interfaces, vol. 4, no. 1, pp. 178-184, 2012.

[74] W. Song and S. Ge, "Application of antimicrobial nanoparticles in dentistry," Molecules, vol. 24, no. 6, p. 1033, 2019.

[75] M. A. 1. H. De Menezes Oliveira, C. P. Torres, J. M. GomesSilva et al., "Microstructure and mineral composition of dental enamel of permanent and deciduous teeth," Microscopy Research and Technique, vol. 73, no. 5, 2009.

[76] M. Bossù, R. Matassa, M. Relucenti et al., "Morpho-chemical observations of human deciduous teeth enamel in response to biomimetic toothpastes treatment," Materials, vol. 13, no. 8, p. $1803,2020$.

[77] F. Meyer and J. Enax, "Early childhood caries: epidemiology, aetiology, and prevention," International Journal of Dentistry, vol. 2018, Article ID 1415873, 7 pages, 2018.

[78] B. T. Amaechi, "Emerging technologies for diagnosis of dental caries: the road so far," Journal of Applied Physics, vol. 105, no. 10, p. 102047, 2009. 